\title{
リン酸エステル-銅錯体の高分子への可溶化と近赤外線カットフィルターの 熱可塑化への応用
}

\author{
林 直樹*1 $\cdot$ 星 元*2 $\cdot$ 上遠野 浩樹*1
}

（受付 2003 年 11 月 19 日·審査終了 2004 年 3 月 5 日）

\begin{abstract}
要 旨 メタクリロイルオキシエチルリン酸エステルを用いてアクリル樹脂中に銅錯体を導入した近赤 外線吸収性フィルター1)の熱可塑化を目的として，非重合性のリン酸エステル配位子による銅錯体のポリ メチルメタクリレート (PMMA)への導入を検討した. リン酸エステルを配位子として用いて銅錯体を作 製し，PMMAへの溶解性を評価したところ，銅錯体は，アルキルリン酸エステルを用いた時には PMMA 中に溶解しなかったが, エステル基をもつ2-アセトキシブチルリン酸 (ABP)を用いた時には PMMA 中に溶解した。この現象は, 配位子が PMMA 側鎖部分と同じエステル基をむつことで, 銅錯体 とポリマーとの親和性が向上し, 相溶性が向上したことによると考えられる. また，ABPを用いて作製 されたプラスチックフィルターは, 従来の熱硬化型樹脂とほほ同等の分光特性を有し, かつ加熱プレス加 エを行うことができた.これにより熱可塑性の近赤外線吸収性フィルターが得られることがわかった.
\end{abstract}

\section{1 緒言}

金属イオンが錯体を形成した時に，可視光線領域から 近赤外線領域にかけて配位子場によって分裂した $\mathrm{d}$ 軌 道間での電子遷移 $(\mathrm{d}-\mathrm{d}$ 遷移)に基つく光吸収特性を有す る.これを透明材料中に導入することで，その光学特性 を活かした光学材料が実用化されている. 金属イオン錯 体の中でも，とくに銅錯体は可視光線領域を吸収せず, 近赤外線領域を吸収する分光特性を有しており，この特 性を光学材料に応用し, 測光素子, CCD, C-MOS カメ ラなどの視感度補正フィルター, 家屋, ビル, 自動車な との熱線吸収空材，植物育成制御のための農業用資材 などに利用されている.

以前は，このような光学材料は，ガラス製のもののみ であっだ3が，上遠野らはメタクリロイル基を有するリ ン酸エステルを配位子とした銅錯体を MMA と共重合 することで銅錯体を高濃度にアクリル樹脂中に導入し， 銅錯体の光学特性を有する高分子製フィルターを実現し たことを報告した1),4).

この材料の用途を広げるために射出成形，押出成形の ような自由度の高い加工法で成形することが望まれてい る.しかしながら, この樹脂材料は, リン酸エステルそ

*1 吳羽化学工業(株)錦総合研究所光学材研究室 (ङ974-8686 いわき市錦町落合 16)

*2 吳羽化学工業 (株) 錦総合研究所有機合成第二研究室 (画 974-8686いわき市錦町落合 16)
れ自体もしくは銅イオンを介して架橋構造をとっている 熱硬化型の樹脂であるため，これらの加工法を適用する ことはできない，そこで，この樹脂材料の熱可塑化の検 討を行った. 熱可塑化の方法として, 架橋ポイントと なっている銅錯体を，ポリマー鎖から切り離すことを考 えた．考え方を Figure 1 に示す．このような樹脂を光 学材料として用いるためには透明性が求められており, そのためには銅錯体が均一に分散, 溶解していなければ ならない，銅錯体を高分子中に溶解させるためには，外 界となじむような配位子を銅イオンに配位させることが もっとも有効な方法であると考えられる.

本報では，銅錯体の配位子として Scheme 1 に示す各 リン酸エステルについて検討を行い, その構造とモノ マー状態，およびポリマー状態における銅錯体の溶解性 の違いについて考察する.ささらに，ポリマーへの溶解性 の高い銅錯体を用いて, 熱可塑性近赤外線吸収フィル ターを実現したことを報告する.

\section{2 実験}

\section{1 リン酸エステル}

2.1.1 メチルリン酸(MP), エチルリン酸(EP), 2-エ チルヘキシルリン酸(2EHP)

上記化合物は市眅の試薬(モノエステル，シエステル の混合物) (東京化成工業(株)製)をそのまま用いた.

2.1.2 2-アセトキシブチルリン酸(ABP)の合成 最初に酢酸(和光純薬工業(株)製) $240.2 \mathrm{~g}$ と酢酸ナト 

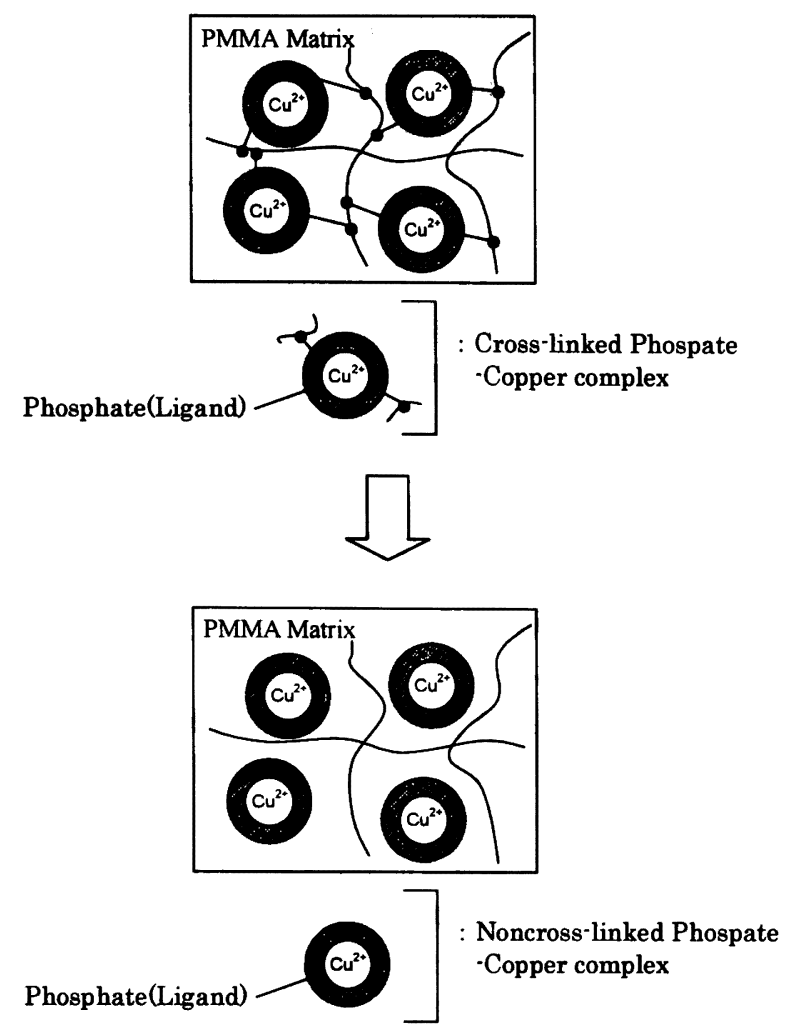

Figure 1. Models of conversion from thermosetting resin to thermoplastic resin.

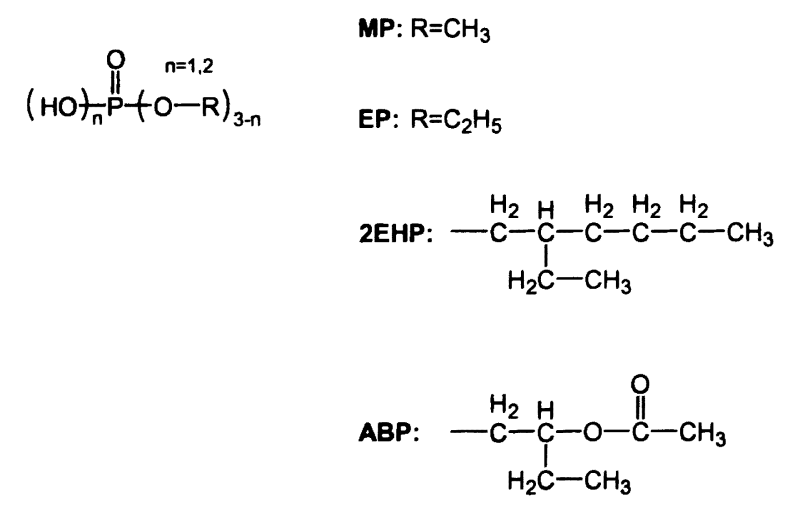

Scheme 1. Phosphate derivatives.

リウム(和光純薬工業(株)製) $16.4 \mathrm{~g}$ を $90^{\circ} \mathrm{C}$ で加熱かく はんしながら，1,2-ブチレンオキサイト(和光純薬工業 (株)製) $288.4 \mathrm{~g}$ を滴下して反応させ，2-ブチレングリ コールモノアセテート $(432.2 \mathrm{~g})$ を合成した. 次に 2-フ チレングリコールモノアセテート $(150 \mathrm{~g})$ とシメトキシ エタン(和光純薬工業(株)製) $150 \mathrm{~mL}$ をかくんし, 反 応温度を $30^{\circ} \mathrm{C}$ 以下に保ちながら五酸化二リンを投入し て反応させ，2-アセトキシブチルリン酸(ABP)(モノエ ステル, ジスステルの混合物)を合成した，反応経路を Figure 2 に示す.

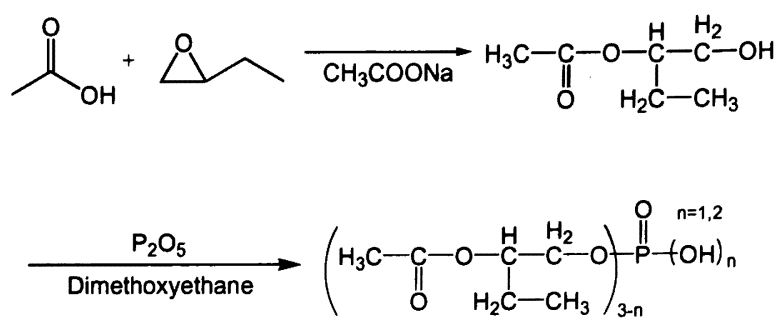

Figure 2. Preparation of ABP.

\section{2 銅錯体の合成}

2.1 節で用意した各リン酸エステルを用いて銅錯体の 合成を行った. 銅イオンとリン酸エステルの量的関係は モル比で $[\mathrm{OH}] /[\mathrm{Cu}]$ が 2.0 の条件下において銅イオン を可溶化できることを上遠野らが報告4)しており，その ようにした，得られた錯体の略称は原料として用いたリ ン酸エステルの略称の末尾に一Cをつけて表した。 $[\mathrm{OH}]$ はリン酸エステル中のリン酸基の $\mathrm{OH}$ 部分のモル 数を意味する. MP, EP, 2EHP の場合にはモノエステ ル成分, シエステル成分の比率から算出し（モル比 $=1$ : 1) $1 \mathrm{~g}$ あたりの $[\mathrm{OH}]$ は $12.60 \mathrm{mmol} / \mathrm{g}, 10.71 \mathrm{mmol} / \mathrm{g}$, $5.63 \mathrm{mmol} / \mathrm{g}$ であった. ABP の場合には $0.1 \mathrm{~N}$ の KOH 水溶液を用いた中和適定により測定し， $4.90 \mathrm{mmol} / \mathrm{g}$ で あった。

\subsubsection{MP-C の合成}

四つロフラスコに MP $10.00 \mathrm{~g}$, 酢酸銅一水和物(和 光純薬工業(株)製)を $12.58 \mathrm{~g}$, トルエン(東京化成工業

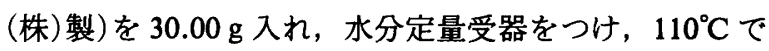
加熱かくはんしながら 4 時間還流を行い, 副生する水打 よび酢酸を除去しながら反応を行った，反応終了後，反 応溶液をナスフラスコに移し，エバポレーターにて乾燥 して $14.15 \mathrm{~g}$ の銅錯体を得た. 得られた銅錯体中の銅イ オン濃度は使用した酢酸銅一水和物および銅錯体の重量 より $4.453 \mathrm{mmol} / \mathrm{g}$ と算出された.

\subsubsection{EP-C の合成}

四つロフラスコに EPを $10.00 \mathrm{~g}$, 酶酸銅一水和物を $10.69 \mathrm{~g}$, トルエンを $30.00 \mathrm{~g}$ 入れ, 2.2.1 項と同様に反 応を行い, $13.81 \mathrm{~g}$ の銅錯体を得た. 得られた銅錯体中 の銅イオン濃度は $3.877 \mathrm{mmol} / \mathrm{g}$ と算出された.

\subsubsection{EHP-C の合成}

四つロフラスコに $2 \mathrm{EHP}$ を $10.00 \mathrm{~g}$, 酢酸銅一水和物 を $5.62 \mathrm{~g}$, トルエンを $30.00 \mathrm{~g}$ 入れ, 2.2.1 項と同様に反 応を行い, $12.09 \mathrm{~g}$ の銅錯体を得た。得られた銅錯体中 の銅イオン浱度は $2.328 \mathrm{mmol} / \mathrm{g}$ と算出された.

\subsubsection{ABP-C の合成}

四つロフラスコに $\mathrm{ABP}$ を $10.00 \mathrm{~g}$, 酢酸銅一水和物を $4.89 \mathrm{~g}$ ，トルエンを $30.00 \mathrm{~g}$ 入れ，2.2.1 項と同様に反応 を行い, $11.55 \mathrm{~g}$ の銅錯体を得た. 得られた銅錯体中の 
銅イオン濃度は $2.121 \mathrm{mmol} / \mathrm{g}$ と算出された.

\section{3 銅錯体の溶解性の評価}

\subsection{1 モノマー状態における溶解性}

モノマー中の銅イオン濃度を $0.1060 \mathrm{mmol} / \mathrm{g}$ とし, モノマー総量が $20 \mathrm{~g}$ となるように, 2.2 節で得られた各 リン酸エステル銅錯体をメチルメタクリレート（MMA） ((株)クラレ製)中に混合してサンブル溶液を作製し，末 溶解銅錯体の有無を調べた。

\subsection{2 ポリマー状態における溶解性}

2.3.1 項の検討で銅錯体が均一に溶解したモノマーに $\alpha$-メチルスチレン(三菱油化(株)製)を $0.04 \mathrm{~g}$, 重合開始 剤として (株)製，パーブチル ND）を $0.20 \mathrm{~g}$ 添加し，厚さ $3 \mathrm{~mm}$ ティスク形成用のモールドに注入して注型重合を行っ た。重合は $40^{\circ} \mathrm{C} て ゙ 8$ 時間, $40^{\circ} \mathrm{C}$ から $65^{\circ} \mathrm{C}$ まで 2 時 間, $65^{\circ} \mathrm{C}$ から $100^{\circ} \mathrm{C}$ をで 1 時間, $100^{\circ} \mathrm{C}$ で 1 時間の温度 プログラムで行った. 重合後, 離型して樹脂板を得た.

得られた樹脂板の濁度を測定し，ポリマー状態での銅錯 体の溶解性を評価した．濁度測定には(株)日本電色製 NDH-1001DP 濁度計を使用した。

\section{4 樹脂板の分光特性}

2.3.2 項の検討で得られた樹脂板の分光特性を評価 し，熱硬化型近赤外線吸収樹脂との比較を行った．分光 評価は Haze 值が 1 以下のものについてのみ行い, 測定 は，紫外/可視/近赤外領域の透過率を(株) 日立製作所製 $\mathrm{U}-4000$ 型分光光度計を使用して $300 \sim 1200 \mathrm{~nm}$ の範囲 で行った.

比較用の熱硬化型樹脂板は, 配位子としてメタクリロ イル基を有するリン酸エステルを用いて作成した．作成 条件は以下の通り.メチルメタクリレート (MMA)（(株) クラレ製) $18.54 \mathrm{~g}$ 中にメタクリロイルオキシエチルリ ン酸(モノエステル，シエステルの混合物) (共栄社化学 (株)製) (PMOE)を $0.81 \mathrm{~g}$ 混合し，これに安息香酸銅 $0.648 \mathrm{~g}$ を混合して完全に溶解させた. 樹脂中の銅イオ ン濃度および銅イオンとリン酸エステルの量的関係は 2.2 節, 2.3 節と同様の条件にそろえた。このモノマー 溶夜に $\alpha$-メチルスチレン, 重合開始剤を添加し, 2.3 .2
項と同様の条件で重合を行った。

\section{5 加熱プレス試験}

2.4 節にて評価した樹脂板を用いて加熱プレス試験を 行った．樹脂板の上下をステンレス製平板で挟み， 0.5 $\mathrm{mm}$ のスペーサーを用いて厚みを規定し， $180^{\circ} \mathrm{C}$ に温度 設定したプレス機にセットした. セット後圧力をかけず に樹脂を軟化させ， 30 秒後に上下から圧力をかけ，30 秒圧力をかけた状態で保持して変形を行った. 加熱ブレ スには (株) 神藤金属工業所製 WF-50 圧縮成形機を使用 した。

\section{3 結果と考察}

\section{1 溶解性試験の結果}

リン酸エステルとして MP, EP, 2EHP，および上記 2.1 節で合成した $\mathrm{ABP}$ を用いて実験 2.2 節の要領で銅 イオンとの錯体を合成し，実験 2.3 節の要領でモノマー 状態でのサンブルの溶解性を調へた。銅錯体が均一に溶 解したものについては重合開始剤を添加し樹脂化を行っ た．使用した銅錯体抢よび MMAの量と，評価結果を Table 1 に示す．モノマー溶液状態での溶解性を比較す ると，2EHP-C, ABP-C を使用した時には完全に溶解 したのに対し，MP-C, EP-C を使用した時には銅錯体 はほとんどMMA に溶解せず沈殿してしまった。

また，2EHP-C および ABP-C を用いて作製したモ） マー溶液を重合し，ポリマーへの溶解性を調べた所, $\mathrm{ABP}-\mathrm{C}$ を用いた場合には得られた樹脂板の Haze $=0.4$ と透明たったが，2EHP-Cを用いた場合には得られ た樹脂板の Haze $=50.7$ と濁っていた．濁った要因は 2EHP-C が PMMA と相分離を起こしたためと考えられ る.これらの結果から，構造の異なるリン酸エステルを 用いて作製した銅錯体は，MMA および PMMA への溶 解性が異なることがわかった。

\section{2 銅錯体の有機䨌囲気への溶解性}

最初にモノマー状態での銅錯体の溶解性について議論 する. 2EHP は銅イオンと錯体形成して水相から有機相 に銅イオンを抽出させる試薬として用いられておりら), 有機相中では 2EHP と銅イオンの錯体が高濃度に溶解

Table 1. Solubility of the phosphate- $\mathrm{Cu}$ (II) complexes in the MMA and the PMMA

\begin{tabular}{|c|c|c|c|c|}
\hline \multicolumn{2}{|c|}{$\begin{array}{c}\text { Phosphate- } \\
\text { Cu(II) complex }\end{array}$} & \multirow{2}{*}{$\operatorname{MMA}(\mathrm{g})$} & \multicolumn{2}{|c|}{ Solubility } \\
\hline & $(\mathrm{g})$ & & In MMA(Monomer) $\left.{ }^{a}\right)$ & In PMMA (Polymer) \\
\hline $\mathrm{MP}-\mathrm{C}$ & 0.48 & 19.52 & - & No Data \\
\hline $\mathrm{EP}-\mathrm{C}$ & 0.55 & 19.45 & - & No Data \\
\hline 2EHP-C & 0.91 & 19.09 & + & 50.7 \\
\hline ABP-C & 1.00 & 19.00 & + & 0.4 \\
\hline
\end{tabular}

Total weight (Phosphate-copper complex $+\mathrm{MMA})=20 \mathrm{~g}$, Concentration of $\mathrm{Cu}^{2+}$ in monomer $=0.1060 \mathrm{mmol} / \mathrm{g}$. a) Soluble, + ; insoluble, - . b) Evaluated by Haze. 
リン酸エステルー銅錯体の高分子への可溶化と近赤外線カットフィルターの熱可塑化への応用

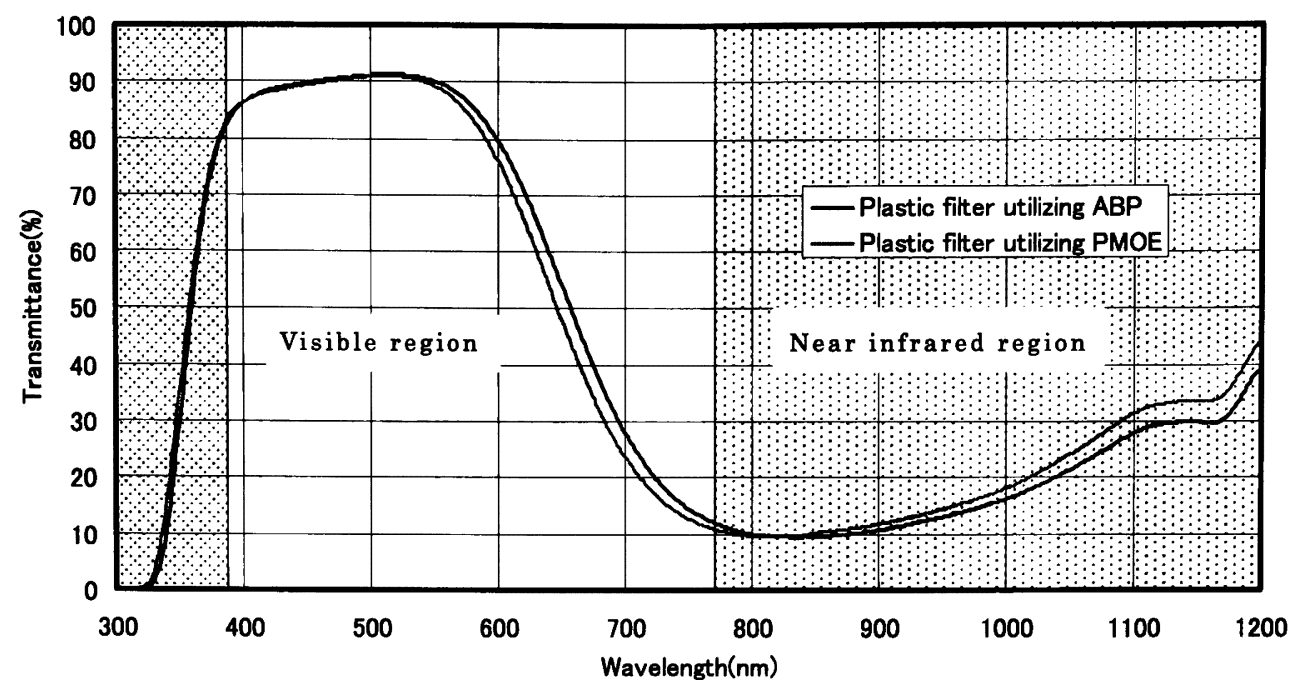

Figure 3. Spectrum of resin plate containing phosphate- $\mathrm{Cu}$ (II) complex.

している時, 逆ミセル会合体を形成することが報告され ている6),7)。この場合, リン酸エステルは配位子である のと同時に，金属を溶解するための界面活性刘の役目を 果たしていると考えることができる. 界面活性㓮と考え た場合，有機相と接するのはその化合物の親油部分であ $\eta$ ，親油部と有機相との親和性がその会合体の溶解性に 影響を与える ${ }^{8)}$.リン酸エステルの場合は有機基の部分 が親油部分に相当しており，この構造が有機溶媒との 相溶性を司ると考えられる.MP-C, EP-C の場合には 有機基が小さいため，金属錯体どうし凝集してしまい MMAに溶解しなかったと考えられる。これに対し， 2EHP-C, ABP-C の場合には，有機基が十分に大きい ため, 親油部分としての特改が十分に発揮され, MMA に溶解できたと考えられる.

次にポリマー状態での銅錯体の溶解性について議論す る. MMAが重合してPMMA となった場合には MMA の動きが拘束され, 混合エントロピー $\Delta \mathrm{S}$ が低下する. そのため, PMMA との親和性が十分に高ければ溶解状 態を保つが，親和性が不十分な場合にはモノマー状態で は溶質とモノマーが溶解していたとしても, ポリマー 状態では相分離が起きることが予想される。ここで, 周 囲の雾囲気と接している，2EHP と ABP の有機基の構 造と PMMA の構造との関係を比較してみた. PMMA は側鎖にメチルエステル基を有する構造である．ABP の場合はメチルエステル基を有していることから， PMMA 側鎖と同じような性質を示すことが予想され， 親和性が高いと推測される. 一方, 2EHP の場合はアル キル基であるため, PMMA との親和性はそれほど高く はないと推測される、そのため, 銅錯体溶液を重合した 時に, 2EHP-C の場合には親和性が十分でないため相 分離が起きてしまったが, ABP-Cの場合には PMMA
との親和性が高く, 重合後にも溶存状態を保つことがで きたと考えられる.

上記結果より，配位子に高分子雾囲気に対して親和性 の高い構造を導入することにより, 高分子中に金属錯体 を溶解させることが可能になることが示唆された.

\section{3 分光特性評価}

この材料の近赤外線カットフィルターとしての性能を 調べるために, $\mathrm{ABP}-\mathrm{C}$ を用いて作成した樹脂板の分光 透過率を測定した. 比較対照として重合性官能基を有す るPMOEを用いて上記 2.4 節の要領で樹脂板を作製 し，同様に分光透過率を測定した．結果を Figure 3 に 示す． ABPを用いて作製した樹脂板は，PMOEを用い て作製した樹脂板とほほ同等の可視光線領域をほとんど 吸収せず，近赤外線領域を広く吸収する分光透過率を示 した.この結果により，銅錯体の配位子として重合官能 基をもたない $\mathrm{ABP}$ を銅イオンの配位子として用いた場 合にも, 重合官能基を有する PMOE を用いたものと, 遜色ない性能をもつことがわかった. 分光特性を発現し ている銅錯体の詳細について調へていくことは，今後の 検討課題と考えている.

\section{4 加熱プレス試験による熱可塑性評価}

上記 3.3 節で分光透過率の評価に使用した, $\mathrm{ABP}$ 打 よび PMOEを用いて作製した樹脂板を用いて加熱プレ 又試験を行い, 加工性を評価した. 最初の 30 秒で樹脂 を融解した後, 上下から圧力をかけてプレス加工を行っ た. 加工前後の樹脂板の外観写真を Figure 4 に示す. PMOEを用いて作製した樹脂はプレス加工を行った が, 粉々になってしまい, 加工することはできなかっ た。 それに対し，ABPを用いて作製した樹脂板は厚さ が $0.5 \mathrm{~mm}$ の透明な樹脂板に加工することができた．さ らに, 得られた表面を研磨し, 上記 2.4 節記載と同様の 


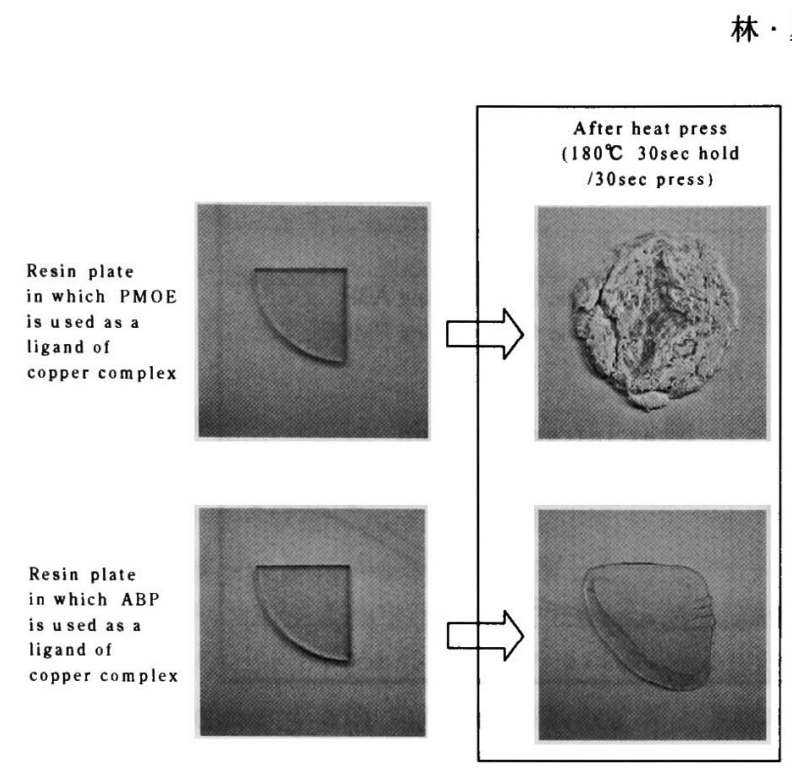

Figure 4. Results of heat press test.

方法で樹脂版の濁度を測定した. 結果は 0.5 を示してお り，溶融加工後も十分な透明性を有していた．これらの 結果により，本報で報告された銅錯体型近赤外線カット フィルターは熱可塑性であることが示された. Figure 1 の考え方の通り，銅錯体を高分子鎖に組込むことなく高
分子に溶解させることで，熱可塑性高分子を作製するこ とができた。

\section{4 結論}

本報では，銅錯体の溶解性と配位子との関係について 調へ，配位子として ABP を用いた時に銅錯体が PMMA 中に高濃度に溶解することがわかった．配位子に高分子 との親和性の高い構造を導入したことにより，銅錯体と 高分子との相溶性が向上したと考察した.これにより， 熱可塑性のプラスチック製近赤外線カットフィルターを 実現した。

\section{文献}

1）上遠野浩樹，阪上輝夫，庄司益宏，荻原武男，高分子論文 集, 54, 417 (1997)

2) 有江英司, 化学々工業, 11, 45 (1994).

3）土橋正二, “ガラスの化学”, 講談社, 東京(1972).

4) H. Katono, T. Sakagami, M. Shouji, and T. Ogiwara, $J$. Appl. Polym. Sci., 67, 903 (1998).

5) P. R. Danesi, Sep. Sci. Technol., 19, 857 (1984).

6) Y. Chevalier and T. Zemb, Rep. Prog. Phys., 53, 279 (1990).

7) C. S. David, T. R. Jenta, and H. R. Brain, Langmuir, 12, 1483 (1996).

8）篠田耕三, “溶液と溶解度”, 丸善, 東京 (1991).

Dissolution of Phosphate-Copper Complex to Polymer and Application to Thermoplastic Resin as Near Infrared Ray Cut-Off Filter Naoki HAYASHI, ${ }^{* 1}$ Hajime Hoshi, ${ }^{* 2}$ and Hiroki Katono ${ }^{* 1}$

${ }^{* 1}$ Optical Material Department, Nishiki Research Laboratories, Kureha Chemical Industry Co., Ltd. (16 Ochiai, Nishiki-machi, Iwaki-shi, Fukushima 974-8686, Japan)

*2Organic Synthesis Department II, Nishiki Research Laboratories, Kureha Chemical Industry Co., Ltd. (16 Ochiai, Nishiki-machi, Iwakishi, Fukushima 974-8686, Japan)

A thermoplastic optical resin filter with the function of cutting off near-infrared rays was prepared by introducing a copper complex into a resin matrix by using acetoxybuthyl-2-phosphate (ABP) phosphate as a ligand of the copper complex. The phosphate-copper complexes were synthesized, and their solubility in polymethylmethacrylate (PMMA) was investigated. The copper complex using alkyl phosphate did not dissolve in PMMA, but the copper complex using ABP did dissolve. ABP has an ester group similar to that on the PMMA side chain structure. It was considered that this group makes the polymer compatible and improves the phosphate-copper complex. The plastic filter with copper complex using $\mathrm{ABP}$ was transformed to a plastic plate $0.5 \mathrm{~mm}$ thick by heat press molding, and showed almost identical spectrum.

KEY WORDS Optical Plastic Filter / Near-Infrared Ray Filter / Phosphate-Copper Complex / Thermoplastic / Solubility of Metal Complexes /

(Received November 19, 2003: Accepted March 5, 2004)

[Kobunshi Ronbunshu, 61(5), 310-314 (2004)] 